\title{
Study of the Quantitative Evaluation of Tourism in Shanghai Based on the World Exhibition or Exposition
}

\author{
Jia Tong Yu \\ Basic Department of College of General Education, \\ Harbin Huade School \\ Harbin, China \\ jiatong_82@163.com
}

\begin{abstract}
To make better analysis on the effect of every stage of the Expo on the tourism in Shanghai and predict Expo effect, the dissertation analyses every stage of the Expo by setting up the autoregression model $\operatorname{ARMA}(p, q)$ and gray model GM(1,1)and using MATLAB and weighted fitting line, and acquires the predicted value of the tourist number entering the country in following five years. The experiment shows that we can get the following points by analyzing data in the table. The Expo can bring the vast tourist source to the tourism in Shanghai, increase income of tourism, push the infrastructure construction of the tourism forward, improve the image of the tourism in Shanghai and realize the evaluation and generalization based on the model.
\end{abstract}

Keywords-component; Harmonic Analysis of Time Series;trend extrapolation ;autoregression model $\operatorname{ARMA(p,q);gray~model~GM(1,1)~}$

\section{INTRODUCTION (HEADING 1)}

Holding the Expo not only marks the economic strong development, but also promotes economic development on some degree in the host country. Nowadays, there are so many studies based on the facilitation of the Expo on the economy, but they are from the following views. From the horizontal point of view, for instance, establishing the accounting model of economic development and measure quantificationally the effect of the Expo on the economic development in Shanghai through the three indexes, including improvement and optimization on the industrial structure of economic development, rising in GDP, improvement of the people life. From longitudinal angel, by building the Synthetic Evaluation Model, fix quantificationally and compare the effect of the Expo on the regional economy in Shanghai Hannover and Osaka.

There are few studies on Expo effect on the city's tourism. To study the effect of the Expo on the tourism in Shanghai benefits the government's reasonable plan tourism and scientific investment and construction. It also has the profound effect on the tourism of Shanghai. By counting the direct and indirect investment in the tourism in Shanghai, setting up the relation model to calculate the total increase value. It also gives detail information about effect of the first stage - the lead-time and the second stage - Exhibition period in the Expo on the tourism in Shanghai and further predicts the influence of the third stage - post Expo effect.

\section{RELATIVE WORKS}

Wherever Times is specified, Times Roman or Times New Roman may be used. If neither is available on your word processor, please use the font closest in appearance to Times. Avoid using bit-mapped fonts if possible. True-Type 1 or Open Type fonts are preferred. Please embed symbol fonts, as well, for math, etc.

\section{A. Model Assumption}

1.Assuming that the current Expo should follow the general pattern, the Fastigium of passenger flow volume of the Expo will appear in the closing day.

2. Assume that the number of people should not be limited.

3. Assume that data on Internet should be reliable.

4. Assume no consideration for the effect of the wave of the entrance fee on the passenger flow volume.

5. Assuming that from the early Sep. to the end of the Aug., Shanghai province should be affected by the bad weather, the extent of the impact of the bad weather on the passenger flow volume of the Expo will decrease.

6. Assume that every random variable doesn't interact with each other.

7. Assume ignoring deviation resulting from emergency.

\section{B. Explanation of Codes}

$X_{t}$ is the former visiting number of people

$\left({ }_{t=1,2, \ldots, 123}\right.$ days $) ; Y_{t}$ is period $\mathrm{t}$ time series

variable; $\alpha$ is the Carry sum of squares weights;

$\varphi_{i}$ is theautoregressive parameters; $\theta_{j}$ is the sliding

average parameters; $\mu_{t}$ is the random variable;

$\varepsilon_{t-j}$ is the period $t-j$ time series variable; $p$ is the autoregressive coefficient; 
$q$ is the sliding average parameters; $k$ is the Variable number of the investment in tourism; $\varepsilon_{t}$ is te dummy variable; $\Delta Y_{t}$ is period $\mathrm{t}$ the increment of the increase value for the tourism; $t$ is the time variable; $K$ isinvestment multiplier; ${ }_{\Delta I_{t}}$ is period the investment increment of the tourism;

\section{ANALYSIS AND RESULTS OF THE EXPERIMENT}

A. ARMA Model obtained by the way of ignoring the effect of the Expo on the Investment of the Tourism

At first, Assuming that in 2010 Shanghai did not hold the Expo,count the direct investment in the tourism in Shanghai during the Expo. Then we can use the time series to predict the tourism investment under the assumption from 2003 to 2010. We can establish the stable model of the time series by autoregression model [1] $\operatorname{ARMA}(p, q)$, the Model $\operatorname{ARMA}(p, q)$ which was shown as follow:

$$
Y_{t}=\sum_{i=1}^{p} \varphi_{i} Y_{t-i}+\sum_{j=1}^{q} \theta_{j} \varepsilon_{t-j}+\mu_{t}
$$

The object suitable for Model $\operatorname{ARMA}(p, q)$ must be stationary. In the short term, statistical characteristic of the time series must not change with the variation of the time. In the long run, time series tends to the constant quantity or linear function.

According to Keynes's Multiplier effect theory [2], the investment model is denoted as follows:

$$
\Delta Y_{t}=K \Delta I_{t}
$$

According to the Registration Report of the 2010 Shanghai World Expo [3],the direct investment of World Expo tourism reached 3.01 billion yuan.

During the programming for the Expo, the Expo villiage has been considered as the comprehensive community for the tourism, business, recreation, and so forth. Therefore, it is feasible to view the total investment in the Expo villiage as the direct investment in the tourism in the Expo.

Making a analysis of the stable time series based on the datas of the investment in the tourism in Shanghai from 1980 to 2002, and making full use of the software of the SPSS to induce the linear distribution curve about the investment in tourism in Shanghai, we find the time series is not stationary. So we realign the order of variables of investment in shanghai and form new variables of time series.

Using the software of the SPSS, we analyze the tourism investment by means of difference, and then describe the second-order difference figure. If the second-order difference of tourism investment lay in the trust region on a high degree and stationary, we can make sure that the tourism investment series is an stationary time series, and then make an analysis on the time series for the investment in the tourism in Shanghai.

Next we ignores the effect of the Expo on the investment in the tourism and establish the Model $\operatorname{ARMA}(p, q)$. We get the following future investment varying model of the investment in the tourism in Shanghai:

$$
Y_{t}=0.19 Y_{t-1}+0.56 Y_{t-2}+\varepsilon_{t}
$$

Apply the above model and engage in the prediction on the investment in tourism facilities of the Expo in Shanghai, As shown in table I:

TABLE I.
\begin{tabular}{|l|c|}
\hline year & TIME SERIES PREDICTION OF THE INVESTMENT IN \\
\hline $\mathbf{2 0 0 3}$ & 19.4 \\
\hline $\mathbf{2 0 0 4}$ & 19.8 \\
\hline $\mathbf{2 0 0 5}$ & 20.0 \\
\hline $\mathbf{2 0 0 6}$ & 20.9 \\
\hline $\mathbf{2 0 0 7}$ & 21.6 \\
\hline $\mathbf{2 0 0 8}$ & 21.7 \\
\hline $\mathbf{2 0 0 9}$ & 21.9 \\
\hline $\mathbf{2 0 1 0}$ & 22.9 \\
\hline Total & 168.2 \\
\hline
\end{tabular}

we can see that the investment in tourism facilities in Shanghai will still increase from 2003 to 2010 without Expo.The gross investment is about 16,800,000,000.

Considering Tourism constitution, tourism transportation investment is also needed to be included into tourism investment. As you can see from table II transportation investment can reached 67.35 billion Yuan, which ensures its status of the international shipping center and the future success of Shanghai World Expo.

TABLE II. TRANSPORTATION INVESTMENT UNDER NO INFLUENCE OF THE WORLD EXPO

\begin{tabular}{|c|c|}
\hline $\begin{array}{c}\text { Transportation } \\
\text { investment }\end{array}$ & $\begin{array}{c}\text { Investment } \\
\text { in } \\
\text { Tourism } \\
\text { Facilities }\end{array}$ \\
\hline City High road & 15 \\
\hline $\begin{array}{c}\text { The intercity } \\
\text { high-speed road }\end{array}$ & 131.5 \\
\hline Rail traffic & 280 \\
\hline Airport Construction & 197 \\
\hline $\begin{array}{c}\text { added carports and } \\
\text { parking lots in Pixy }\end{array}$ & 50 \\
\hline total & $\mathbf{6 7 3 . 5}$ \\
\hline
\end{tabular}

From table I and table II, we can conclude that the total investment of Shanghai tourism investment is 84.17 billion Yuan.

B. Building investment model of reflecting the indirect influence of world Expo

Since won the world expo bid, Shanghai actively improves its environment for tourism development, lifts the limit for tourism indirect investment. According to statistics, 
the world expo will bring 0.25 related investment rates, and formula is as follows :

Related investment rate $=$ (real investment - expected investment) / real investment[4]

Combined with the tourism investment free from the world expo influence, we can further calculated that under the influence of the world expo during year $2003 \sim 2010$, the total investment of Shanghai tourism is about 111.55 billion Yuan. Among them the world expo factors brought about a total investment of 27.38 billion Yuan.

Since 2002, shanghai won the world expo bid, it has seven years of preparation.The World Expo did the most part to contribute to A series of tourism investment [5] The total tourism investment of world expo includes both the world expo direct and indirect tourism investment, 3.01 billion Yuan and 27.38 billion Yuan respectively, in total , While the world expo bring 30.39 billion Yuan growth to Shanghai tourism investment.

Using added value and investment increment statistics of tourism industry during year $1980 \sim 2002$, we can perform the regression estimate, And the result is as follows table III.

TABLE III. REGRESSION COEFFICIENT(A)

\begin{tabular}{|l|l|c|c|c|c|}
\hline \multirow{2}{*}{ project } & \multicolumn{2}{|l|}{$\begin{array}{l}\text { Non standard } \\
\text { coefficient }\end{array}$} & $\begin{array}{l}\text { Standard } \\
\text { coefficient }\end{array}$ & $\begin{array}{l}\text { The } \\
\text { value } \\
\text { of T }\end{array}$ & $\begin{array}{l}\text { Significant } \\
\text { degree. }\end{array}$ \\
\cline { 2 - 5 } & $\boldsymbol{B}$ & std.ert & beta & & 0.000 \\
\hline $\begin{array}{l}\text { Constant } \\
\text { I volume }\end{array}$ & 13.824 & 3.259 & & 4.242 & 0.376 \\
\hline $\begin{array}{l}\text { Tourism } \\
\text { nvestmen } \\
\text { t increase }\end{array}$ & 0.725 & 0.801 & 0.198 & 0.905 & \\
\hline
\end{tabular}

We can see, under the confidence level ,The regression equation is significant and The final regression Coefficient(a) will be

$$
\Delta Y_{t}=0.73 \Delta I_{t}+13.824 \quad \text { (4) }
$$

The investment multiplier is 0.73 , (the ratio between the tourism investment increase and the value incremental), in other words,. According to the estimated total tourism investment ,we can calculate that the Expo bring 24.102 billion Yuan added value increment.

\section{Quantitative analysis on the three stages of the World Expo to Shanghai tourism}

A full economic cycle duration of Expo which is divided into three stages is about 10 to 12 years, the first stage of the preparatory phase lasted about seven years. The second stage is the World Expo stage in which a large number of tourists gathered in Shanghai, showing increase in consumer demand and stimulating tourism revenue. the third stage of the World Expo is called the post Expo stage (3 to 5 years), which is likely to produce the dip effect on the slum tourism or bring about the positive effect on the development of the tourism industry

1) Effects on domestic tourism in the preparatory phase of Shanghai World Expo

Seven years from 2002 to 2009 is known as the Expo preparatory period, during which the early effect on the tourism of World Expo was becoming apparent. Since the start of 2001, besides the SARS damage in 2003, foreign exchange income of overseas tourists and international tourism in Shanghai rose steadily, this has dramatically increased the number of tourists and tourism revenue than before. But the cost of the infrastructure of the Expo area indirectly effect the revenue growth of Shanghai tourism.

2) Effects on domestic tourism in the period of Shanghai World Expo

Compared with the same period in 2009, the number of foreign tourist arrivals in World Expo increased significantly from May 2010 to August 2010. A large number of tourists gathering in Shanghai showed strong growth in consuming demand, which boosted the tourism revenue.

3 ) The broadcasting results on domestic tourism in the post period of Shanghai World Expo

Rational use of Expo venues will help extend the influence exerted by World Expo to 3-7 years in the Post World Expo stage.

based on MATLAB method we can get the optimal parameter of evaluation model of next 5 years' number of inbound tourists. $a=0.41331359425$,

$b=2.0426 e+002$, Grey System Method GM(1, l) [6] model is used here to predict the number of inbound tourists and tourism revenue of Shanghai in the following 5 years in table 4.

After three times of modeling analysis on residual sequence[7], the optimal parameter of evaluation model of tourist number is $a=0.063793, b=7988.2181$. The forecast value of next 5 years' number of inbound tourists is $x(t+1)=619 \exp (0.41331359)+560.998580$

based on this value, the optimal parameter of evaluation model of tourist exchange revenue is

$$
a=0.2654938599, b=1.700928
$$

and the forecast value of exchange revenue of Shanghai is $x(t+1)=-36.410140 \exp (0.045034)+37.769674$. the optimal parameter of evaluation model of tourist exchange revenue is

$$
a=-0.27354, b=17.077658
$$

and forecast value of domestic tourist revenue is

$$
x(t+1)=1612.32011 \exp (0.27354)-1611.1 .
$$

TABLE IV. 2002 2009 DOMESTIC TOURISM OVERVIEW OF SHANGHAI

\begin{tabular}{|l|l|l|l|l|}
\hline Year & \multicolumn{1}{|c|}{$\begin{array}{c}\text { Domestic } \\
\text { number } \\
\text { of tourist } \\
\text { thousand) }\end{array}$} & $\begin{array}{c}\text { Annual } \\
\text { Growth } \\
\text { Rate } \\
\mathbf{( \% )}\end{array}$ & $\begin{array}{c}\text { Domestic } \\
\text { Tourist } \\
\text { Revenue } \\
(\mathbf{1 0 0} \\
\text { million) }\end{array}$ & $\begin{array}{c}\text { Annual } \\
\text { Growth } \\
\text { Rate } \\
(\mathbf{\%})\end{array}$ \\
\hline $\mathbf{2 0 0 2}$ & 8761 & 6.1 & 993.4 & -1.6 \\
\hline $\mathbf{2 0 0 3}$ & 7603 & -13.2 & 1406.1 & 41.5 \\
\hline $\mathbf{2 0 0 4}$ & 8505 & 11.8 & 1216 & -13.5 \\
\hline $\mathbf{2 0 0 5}$ & 9012 & 5.9 & 1308.5 & 7.5 \\
\hline $\mathbf{2 0 0 6}$ & 9684 & 7.4 & 1419.6 & 8.4 \\
\hline $\mathbf{2 0 0 7}$ & 10210 & 5.4 & 1611.1 & 13.5 \\
\hline $\mathbf{2 0 0 8}$ & 11006 & 7.8 & 1612.3 & 0.005 \\
\hline
\end{tabular}




\begin{tabular}{|l|l|l|l|l|}
\hline $\mathbf{2 0 0 9}$ & 12361 & 12.3 & 1913.4 & 18.6 \\
\hline
\end{tabular}

TABLE V. DOMESTIC NUMBER OF TOURISTS AND TOURIST REVENUE OF SHANGHAI IN NEXT 5 YEARS

\begin{tabular}{|c|l|l|}
\hline Year & $\begin{array}{c}\text { Forecast Value of } \\
\text { Number of Tourists (10 } \\
\text { thousand) }\end{array}$ & $\begin{array}{c}\text { Forecast Value of Tourist } \\
\text { Revenue (100 million) }\end{array}$ \\
\hline $\mathbf{2 0 1 0}$ & $\mathrm{x}(\mathrm{t}+1)=14190.4$ & $\mathrm{x}(\mathrm{t}+1)=2930.0$ \\
\hline $\mathbf{2 0 1 1}$ & $\mathrm{x}(\mathrm{t}+2)=12920.2$ & $\mathrm{x}(\mathrm{t}+2)=2355.8$ \\
\hline $\mathbf{2 0 1 2}$ & $\mathrm{x}(\mathrm{t}+3)=12581.9$ & $\mathrm{x}(\mathrm{t}+3)=2973.6$ \\
\hline $\mathbf{2 0 1 3}$ & $\mathrm{x}(\mathrm{t}+4)=11227.9$ & $\mathrm{x}(\mathrm{t}+4)=3167.4$ \\
\hline $\mathbf{2 0 1 4}$ & $\mathrm{x}(\mathrm{t}+5)=10314.6$ & $\mathrm{x}(\mathrm{t}+5)=3474.5$ \\
\hline
\end{tabular}

As factors of World Expo's influence on tourism are aboundant, it is difficult to give detailed analysis for every one of them , there may be more or less error compared with the real situation. Take 2010 statistic data for example, the number of domestic tourists is 224 million, with annual growth rate $2.9 \%$, domestic tourist revenue is 254.246 billion RMB. [8]

\section{CONCLUSION}

In modern society, event tourism receives wide attention from academia. It has a profound effect on host venues. In past researches, researchers laid emphasis on positive effects on event tourism activities, such as impeccable infrastructures, refashioning city image and promotion of tourism sustainable development. The mathematical model discussed in this article has some certain practical significance and reference on researches on influences brought by event tourism. The classical prediction model, i.e. grey prediction model $\mathrm{GM}(1,1)$ can be applied in predicting various similar issues.

However, it is relatively dependent on historical statistics and ignores the connections among all elements. Hence, it is not applicable to medium-and long-term prediction model. In order to reduce deviation, subsection prediction has to be adopted. It divides five years into five segments and makes further analysis and prediction of each step respectively to get more optimum results. Hereafter, we can do more profound and concrete researches about relationships among tourists' expectations, satisfaction and revisitings.

\section{REFERENCES}

[1] L. Zhao, Influence of Shanghai EXPO on Tourism and Countermeasures to Travel Agencies[A], MARKET FORUM, 2006(2)

[2] J.M. Kane Maxwell, The General Theory of Employment, Interest, and Money, Beijing: the commercial press, 1999:pp 30-31.

[3] 2010 Shanghai EXPO Registered Report(Abstract Five).

[4] Y.Z. Wang,P.F. Zhu,S.Y. Xie, Quantitative Analysis of Influences of 2010 Shanghai EXPO on Economic Aggregate and Structure in Shanghai, July, 2010.

[5] Shanghai Statistics Yearbook (1980-2010) .

[6] F. Duan, F. Yang, Research and Application of Grey Forecasting Model[J], Journal of Xiangnan University, 2008,4 (29) : Page1721.

[7] S. Liu,Y. Wang,F.G. Hu, On the Residual Error of Grey Forecasting Model, Statistics and Policy Making, 2008, 1: page 9-11.

[8] Official Website of 2010 Shanghai EXPO: http://www.expo2010china.com,2010. 